\title{
Water Balance of a Boreal Black Schist Heap Leach Operation
}

\author{
Antti Arpalahti ${ }^{1}$ D $\cdot$ Mari Lundström ${ }^{2}$
}

Received: 9 August 2019 / Accepted: 20 May 2020 / Published online: 29 May 2020

(c) The Author(s) 2020

\begin{abstract}
The current study presents the effect of process chemistry as well as climate conditions on the water balance of a heap leach operation for black-schist ore. The research is based on the actual water balance at the Terrafame (former Talvivaara) mine site in Finland during the years 2017 and 2018 (base case). In addition, scenarios with a deviation in climatic conditions (Antofagasta case), chemistry (non-heat generation case) and effects of climate change (RCP4.5 (representative concentration pathway) case and $R C P 8.5$ case) were investigated. In the first case, the annual precipitation and evaporation were simulated for a highly arid climate such as in the Antofagasta Mountains, whereas in the second case, an assumption was made of no excess heat generation (exothermic reactions) in the heap reactions. The base case predicted a requirement of 9,000,000 $\mathrm{m}^{3}$ annual discharge of water from the site with the heaviest annual rainfall. The discharge requirement and therefore the water footprint of the plant was shown to be highly dependent on the climatic conditions, as the Antofagasta case predicted a discharge of water from the site as low as zero. Heat generation, typical of the reactions dominating in a boreal black-schist heap leach operation, was shown to be vital for water management operations and therefore discharge management in Nordic climatic conditions (the non-heat generation case), where the discharge requirement was shown to be nearly threefold compared to the base case (2018). If the black-schist ore body resided in Antofagasta, the freshwater consumption would be over eight times the current consumption in the base case in Finland. Climate change scenarios show that the changing climate would increase the range of variation but only increase the need for water discharge from the site by $5 \%$ in the wettest years, while raw water utilization would increase by 46 to $83 \%$ during the driest years. In general, the results highlight the issues related to the mass and energy balance of a heap leach nickel process, and therefore feasibility - showing that although the heat generation is ore- and process-specific, the water consumption as well as discharge to the surrounding environment is highly dependent on the climatic conditions (precipitation, temperature) in the geographical location.
\end{abstract}

Keywords Climate conditions $\cdot$ Nickel process $\cdot$ Sulfide ore $\cdot$ Global warming

\section{Introduction}

The importance of nickel and cobalt mining has increased along with electrification; both metals are required as raw materials for batteries. Battery production in the world in 2025 is forecast to be $500 \mathrm{GWh}$, up from $120 \mathrm{GWh}$ in 2017. This indicates the consumption of almost $60 \%$ of annually produced $\mathrm{Co}$ and $10 \%$ of $\mathrm{Ni}$ for battery needs alone (European Commission 2018). Therefore, it is evident that an increase in mining as well as a better understanding of the

Antti Arpalahti

antti.arpalahti@terrafame.fi

1 Terrafame, Malmitie 66, 88120 Tuhkakylä, Finland

2 School of Chemical Engineering, Aalto University, P.O. Box 16100, 00076 Aalto, Finland chemistry related to battery metals production are a necessity. All mines utilize water to support mining, mineral processing, and metals recovery. The challenges associated with the water balance (need, consumption, discharge) differ greatly in arid and wet conditions. The Terrafame operation, located in northern Finland (Terrafame 2017), is a unique case in many aspects. It uses an oxidative heap leaching process in boreal conditions, where the ambient temperature falls below $-30{ }^{\circ} \mathrm{C}$ during the coldest winters. In this geographical area, there is also a net precipitation of water every year. In addition to extreme weather conditions, the reactive nature of the ore results in minor metal cation dissolution in contact with rainwater, typical of sulfide ores. The reactive nature of the Terrafame orebody was evident before mining began (Parviainen and Loukola-Ruskeeniemi 2019). As a result, wide areas of the heap leach operation 
transform rainwater to pregnant leach solution (PLS) or contaminated water. Mine water problems are certainly not unique to Nordic operations and are widely discussed in the scientific literature (e.g. Attiogbe 2017; Gasparon et al. 2007; Jhariya et al. 2016; Ochieng et al. 2010; Rybnikova and Rybnikov 2017).

The average annual rainfall (with both rain as water and the water value of snow) at the Terrafame mine site is $\approx$ $730 \mathrm{~mm}$, according to local weather station readings from 1962 to 2008 , with observations ranging from $\approx 500$ to $1000 \mathrm{~mm}$. The estimated annual ground evaporation average is $300 \mathrm{~mm}$, with observations ranging from $\approx 230$ to $355 \mathrm{~mm}$. Historically, the accumulation of snow on the ground starts from October and has mostly melted away in April (FEI 2019). This is atypical for heap leaching, which is more commonly located in dry areas (Ghorbani et al. 2016). For example, in the Antofagasta region of Chile-an important mining area that contributes $63 \%$ of Chile's gross national product (ICA 2017) - the average annual rainfall was $1.7 \mathrm{~mm}$ between 1961 and 1990 (INE 2017). This is $0.23 \%$ of the average at the Terrafame mine. Therefore, at the Terrafame operation, natural water accumulation challenges the discharge operation with a substantial excess of water, whereas in the Antofagasta type of climate, the challenge is the lack of fresh water. So, for example, while the Zaldivar operation in Antofagasta had to look for a fresh water source $100 \mathrm{~km}$ away from the mine (Lo 1996), the Terrafame operation had to apply for a permit to discharge excess water from the mine area (Terrafame 2017). Another example of a mine area in a dry climate is Kalgoorlie in Western Australia. There, average annual rainfall is $268 \mathrm{~mm} / \mathrm{a}$ (BOM 2019) while the annual evaporation is $\approx 250 \mathrm{~mm} / \mathrm{a}$ (Sudmeyer 2016). However, the challenges at Terrafame are not totally unique. For example, in the Congo Basin, the annual average rainfall is $1430 \mathrm{~mm} / \mathrm{a}$ (Munzimi and Hansen 2015) and the annual mean evaporation $1098 \mathrm{~mm}$ (Chishugi and Alemaw 2009). While both rainfall and evaporation are greater than at Terrafame, the difference between the two is similar.

Krogerus and Pasanen (2016) studied the water balance at the Yara Siilinjärvi and Boliden Kylylahti mine sites, located $\approx 100 \mathrm{~km}$ south and $140 \mathrm{~km}$ southeast of the Terrafame mine, respectively. They presented geological, geophysical, and surface water studies, and suggested actions for water management. Kauppila et al. (2011) listed the water balance factors at the Terrafame mine. The data from 2009 (after one year of mining) predicted practically no discharge from the site. After a longer period of mine operation, it became evident that discharge was necessary (Terrafame 2017).

Punkkinen et al. (2016) presented the elements required for a sufficient water balance, starting from precipitation, evapotranspiration, runoff, and changes in water storage, and then splitting the balance into processing, natural, and tailings dam waters. They further discussed the modeling software options: deterministic, spreadsheet-type models and probabilistic, dynamic models. Their advice was to use dynamic (complex) probabilistic models, which has been criticized for possibly leading to over-engineering and hence potentially damaging project evaluations (Swanson et al. 2016). While complex modeling programs may have their benefits, there is little that cannot be performed with a spreadsheet model in able hands. Ultimately, the reliability of a model depends on the quality of the inputs and the awareness of the users. A typical water balance in nature is in the form of Eq. (1):

$d_{\text {Inventory }}=P-E-R o+R i$

where $d_{\text {Inventory }}$ is the change of water volume in the balance area (pond, ground, etc.), $P$ is the precipitation (rainfall) in the balance area, $E$ is the evaporation from the balance area, $R o$ is the runoff (flow out) from the balance area to adjacent areas, and $R i$ is the opposite of runoff, flow from adjacent areas into the balance area.

This balance changes at a mine for several reasons. A mining operation where ore is removed from the ground typically mines a relatively dry material; the processing of this material typically adds moisture to it, which requires a water source. Also, the operation might use water for other processing purposes, especially in the hydrometallurgical industry. On the other hand, runoff is generally undesirable from a mining operation if the rainwater comes into contact with contaminating material at the mine site. Hence, there is typically a discharge purification step that is governed by an environmental permit. As an example, recent permitted components at Finnish mines, metal plants, and a recently built pulp mill are listed in Table 1. Furthermore, due to the potential of water contamination, mining operations should avoid run-on from nearby areas into the mining areas where the risk of contamination exists. This could be arranged by creating preferred flow patterns for runoff streams with ditches and pumping if necessary. Environmental permits depend greatly on the type and size of the plant as well as the geographical location and discharge possibilities. A typical mine water balance is in the form of Eq. (2):

$d_{I n v}=P-E-O w+P w-D$

where $d_{I n v}$ is the change in water volume in mine ponds and dams, $P$ is the precipitation in the mine area, $E$ is the evaporation from the mine area, $O w$ is the new ore-bound moisture during processing, $P w$ is the other process water used apart from rainwater (e.g. fresh lake water), and $D$ is the discharge of water from the mine site (bleed).

The current study investigated the water balance of the Terrafame operation with different scenarios. The reactivity of the ore and the amount of heat generated at the Terrafame heaps are extraordinary for heap leach operations (Arpalahti 
Table 1 Examples of recent permitted concentrations $(\mathrm{mg} / \mathrm{L})$ and amounts of dissolved species $(\mathrm{t} / \mathrm{a})$ in the discharge solution of Finnish industrial sites

\begin{tabular}{|c|c|c|c|c|c|c|c|c|c|}
\hline Site & Products & $\mathrm{Ni}$ & $\mathrm{Cu}$ & $\mathrm{SO}_{4}$ & $\mathrm{Ni}$ & $\mathrm{Cu}$ & $\mathrm{SO}_{4}$ & Note & Ref \\
\hline Terrafame & $\mathrm{Ni}, \mathrm{Zn}, \mathrm{Cu}, \mathrm{Co}$ precipitates & 0.3 & 0.3 & 3,000 & 0.35 & 0.1 & 24,000 & Pending application & (AVI 2018) \\
\hline Boliden Kevitsa & $\mathrm{Cu}, \mathrm{Ni}$ concentrates & 0.3 & 0.1 & 2,000 & 0.65 & 0.2 & 4,333 & $\begin{array}{l}\text { Calculated } \mathrm{SO}_{4}(\text { in } \mathrm{t}) \text {, not men- } \\
\text { tioned in permit }\end{array}$ & (AVI 2014a) \\
\hline Nornik & $\mathrm{Ni}$, Co products & 2 & 0.5 & 16,500 & 0.365 & 0.09 & 36,000 & $\begin{array}{l}\mathrm{SO}_{4}(\mathrm{mg} / \mathrm{L}) \text { not mentioned in } \\
\text { permit, approximated by the } \\
\text { information in the permit, } \mathrm{Cu} \\
\text { tonnes calculated }\end{array}$ & (AVI 2014b) \\
\hline Boliden Kokkola & $\mathrm{Zn}$ & N/A & N/A & N/A & 10 & 0.5 & N/A & $\begin{array}{l}\text { Permits shared by production } \\
\text { site operations. } \mathrm{SO}_{4} \text { not men- } \\
\text { tioned at all }\end{array}$ & (AVI 2008) \\
\hline Agnico Eagle Kittilä & $\mathrm{Au}$ & 0.3 & N/A & 2,000 & N/A & N/A & 5,500 & & (AVI 2013) \\
\hline Metsä Fibre Äänekoski & Cellulose products & N/A & N/A & 778 & N/A & N/A & 35,478 & $\begin{array}{l}\mathrm{SO}_{4} \text { not mentioned or limited in } \\
\text { the permit, approximated by } \\
\text { the Na amounts }\end{array}$ & (AVI 2015) \\
\hline
\end{tabular}

and Lundström 2017). This offers the potential to go beyond natural ground evaporation, which, in a net positive rainfall area, is a positive factor for water management. The objective was to compare water balance scenarios at a site where the ore is not as reactive, and where the operation would be located in an arid area, such as the Antofagasta Mountains. The observations were carried out using local climate data (INE 2017; FEI 2019) and the 2018 base case water balance. Furthermore, the effects of climate change on the Terrafame water balance were estimated using different scenarios, to obtain predictions of the future water balance.

\section{Materials and Methods}

\section{Scenarios}

The current study is based on the actual water balance at the Terrafame mine site in Finland during the calendar years 2017 and 2018 (base case). This period was selected because the primary heap area of the plant was fully constructed by the beginning of 2017, and consequently these 2 years represent a full-scale operational water balance for the mine. In the base case, the range of rainfall and evaporation were also compared with sub-scenarios of the wettest and driest year between 1962 and 2008 (FEI 2019). For the maximum rain and minimum evaporation, a rainfall of $1,000 \mathrm{~mm}$ and ground evaporation of $230 \mathrm{~mm}$ were used and in the base case with minimum rainfall and maximum evaporation, a rainfall of $500 \mathrm{~mm}$ and ground evaporation of $355 \mathrm{~mm}$ were used.

In addition, scenarios with different climatic conditions (Antofagasta case) or chemistry (non-heat generation case) were investigated. In all of the considered additional scenarios, the transfer of solutions was adjusted to keep the water inventory levels within the annual balance. The Antofagasta case assumed the orebody to be located in the Antofagasta Mountains, a very dry climate, with an annual rainfall of only $1.7 \mathrm{~mm}$ (INE 2017). In this scenario, the evaporation was assumed to equal the precipitation on the water side of the balance, and $300 \mathrm{~mm}$ per annum on the PLS side, as the heaps are kept wet by irrigation.

In the non-heat generation case, the focus was on the chemistry of the orebody in the heap, not producing enough heat to generate any extra evaporation. The Terrafame ore produces a large amount of heat and that extra evaporation helps in dealing with the positive net precipitation (rainfall minus ground evaporation) of water. In this scenario, the average rainfall and evaporation data were taken from the Terrafame area (FEI 2019).

Lastly, the effect of climate change was estimated up to 2085 by generating four extra scenarios based on the base case: two scenarios with the representative concentration pathway (RCP) of 4.5 and two scenarios with a RCP of 8.5. The RCP number signifies the magnitude of greenhouse gasses and particles on the heat balance of the world in watts per $\mathrm{m}^{2}$ by the year 2100 . The RCP8.5 case signifies the worstcase climate change estimated, i.e. over triple $\mathrm{CO}_{2}$ emissions worldwide by the year 2100 compared to the pre-industrial era, while in the RCP4.5 case, the emissions of $\mathrm{CO}_{2}$ are merely doubled by the year 2100 from the pre-industrial era (Ruosteenoja 2013). The year 2085 was selected because it was the end point of the data in Ruosteenoja (2013).

The precipitation in Finland is estimated to increase by $12.5 \%$ and $20 \%$ for the RCP4.5 and RCP8.5 cases, respectively, by 2085 (Ruosteenoja 2013). It was assumed for the purpose of this article that the ranges of variation change by the same percentage. These values were used to alter the precipitation range: the maximum precipitation from the base case $(1000 \mathrm{~mm})$ to $1,125 \mathrm{~mm}$ for the RCP4.5 case and 
$1200 \mathrm{~mm}$ for the RCP8.5 case and the minimum precipitation from base case $(500 \mathrm{~mm})$ to $563 \mathrm{~mm}$ in the RCP4.5 case and $600 \mathrm{~mm}$ in the RCP8.5 case.

The increment in temperature at the same point, in 2085, is estimated to be $3.7^{\circ} \mathrm{C}$ in the $R C P 4.5$ case and $6^{\circ} \mathrm{C}$ in the $R C P 8.5$ case. The effect on ground evaporation is not listed and therefore has to be estimated separately. Monthly data of ground evaporation as a function of temperature was tracked (FEI 2019) in Fig. 1.

Plotting the data in Fig. 1, the increased temperature due to climate change can be estimated by monthly increasing the temperature. As a result, the annual ground evaporation increases by $45 \%$ and $77 \%$ in the RCP4.5 and RCP8.5 cases, respectively, for an average year and it is assumed to change with the same percentage magnitude for the range of change observed. This was used to alter the minimum evaporation from the base case $(230 \mathrm{~mm}$ ) to $333 \mathrm{~mm}$ in the RCP4.5 case

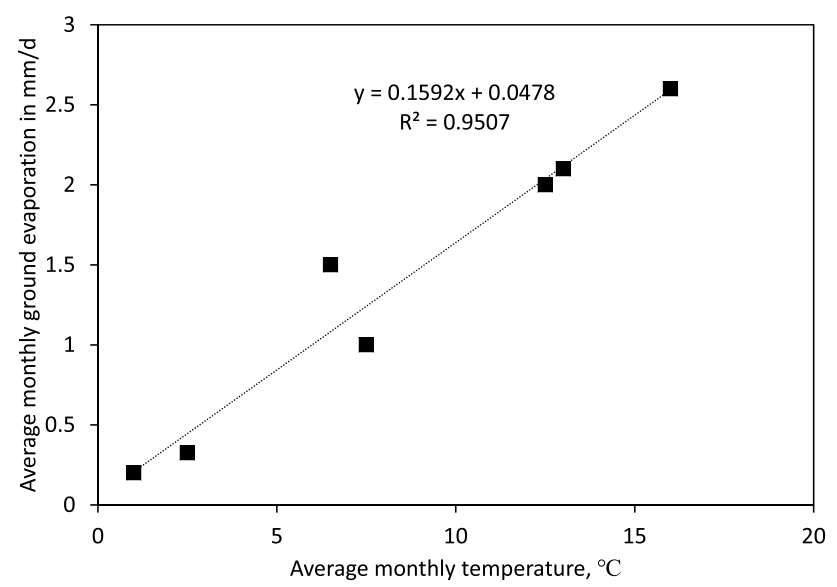

Fig. 1 Ground evaporation in $\mathrm{mm} / \mathrm{d}$ as a function of average temperature in ${ }^{\circ} \mathrm{C}$ (FEI 2019) and $406 \mathrm{~mm}$ in the RCP8.5 case and maximum evaporation from the base case of $355 \mathrm{~mm}$ to $513 \mathrm{~mm}$ in the RCP4.5 case and $627 \mathrm{~mm}$ in the RCP8.5 case.

\section{Water Balance Modeling}

The water balance was split into two parts: (i) the process circuit with the PLS, covering the heap leach area and the metals recovery plant (containing a significant amount of metals); and (ii) the water circuit, catching water in the mine, for example and containing a small amount of metals from contact with the ore or waste rock.

The following parameters influencing the total water balance at Terrafame were observed: the catchment area for rainfall and ground evaporation, rainfall, ground evaporation, the metals recovery plant water balance of usage and/ or return to process circulation, the moisture bound to new ore during the leaching process, and discharge of water from the site. Figure 2 presents the parameters contributing to the PLS and water circuit balances.

The water balance, as defined above, differs from the water balance in nature. In nature, variables such as the surface water flow to and from the balance area has to be accounted for. The PLS circuit area is lined with a geotextile and the solution is contained within the lined area. Similarly, the water circuit area is surrounded by a ditch system to prevent water from entering or leaving. The water in the PLS or water circuit is assumed not to penetrate the groundwater at a significant rate. It is also assumed that the bonding of water to material is negligible in the water management ponds and area, though there is a significant effect of water bonding to the crushed ore at the PLS circuit. The water balance is therefore defined by Eqs. (3) and (4):
Fig. 2 The parameters contributing to the PLS (pregnant leach solution) and water circuit balances

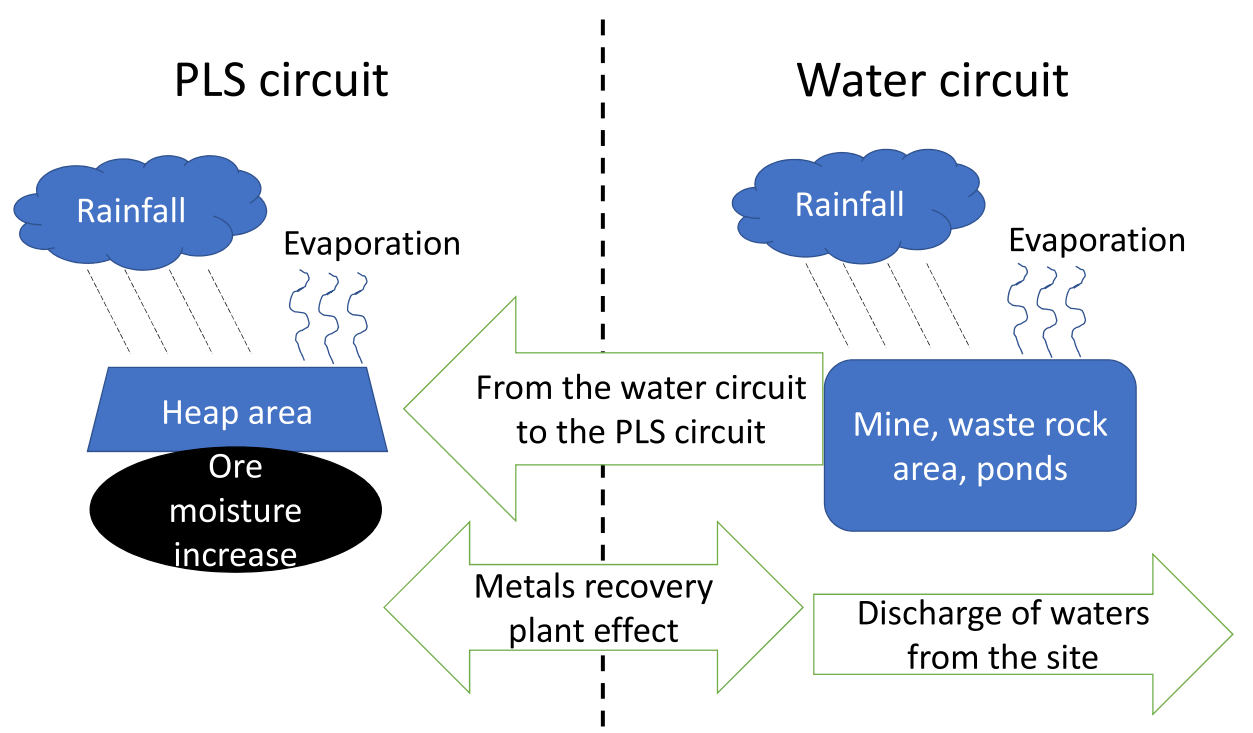


$d_{\text {InventoryPLS }}=P_{\text {heaps }}-E_{\text {ground,heaps }}-E_{\text {extra,heaps }}-O w+/-M_{P L S}+W w$

where $d_{\text {InventoryPLS }}$ is the change in PLS volume in the ponds, $P_{\text {heaps }}$ is the precipitation in the heap leaching area, $E_{\text {ground,heaps }}$ is the ground evaporation from the heap leaching area, $E_{\text {extra,heaps }}$ is the evaporation from the heap leaching area caused by the heat of reaction, $O w$ is the new ore-bound moisture, $M_{P L S}$ is the effect of the metals recovery plant on the PLS balance, and $W w$ is the water from the water ponds transferred to the PLS ponds.

$d_{\text {Inventorywater }}=P_{\text {water }}-E_{\text {water }}+/-M w-W w-D$

where $d_{\text {Inventorywater }}$ is the change in water volume in the mine water ponds and dams, $P_{\text {water }}$ is the precipitation in the mine area where risk of contamination exists, $E_{\text {water }}$ is the evaporation from the mine area, excluding the heaps, $M w$ is the effect of the metals recovery plant on the water balance, $W w$ is the water from the water ponds transferred to the PLS ponds, and $D$ is the discharge of water from the mine site.

\section{Parameters}

Catchment area: The heap leach and other PLS circuit rainfall catchment area was 580 ha in both 2017 and 2018. The water circuit rainfall catchment area grew from 1080 ha in 2017 to 1330 ha in 2018 as the area of lined waste rock was increased.

Rainfall: The rainfall was monitored daily at the mine site by measuring the new water in a container during the time that rainfall fell as water and by melting the snow that fell in the same container. Thus, the water value of the snow was obtained. However, this was a single measurement on a mine site of $\approx 60 \mathrm{~km}^{2}$, which adds potential error to the analysis of the water balance.

Ground evaporation: The ground evaporation was monitored daily from a Finnish Environment Institute weather station near the mine site (FEI 2019), Fig. 3. The summer is short in the region of the mine and the daily average temperature remains below $0{ }^{\circ} \mathrm{C}$ for nearly half of the year, below the freezing point of water. As this period starts from before the change of year, there is a possibility of carry-over of snow from the previous year, adding complexity to the estimation of the annual water balance. As the weather station is approximately $15 \mathrm{~km}$ away from the site, this measurement is also a potential source of error in the analysis of the water balance.

Metals recovery plant solution balance: The metals recovery plant solution balance was tracked by the effect it had on both the PLS and the water circuits. All the flows were tracked with flow meters. The detailed reasons for water usage at the metals recovery plant are beyond the

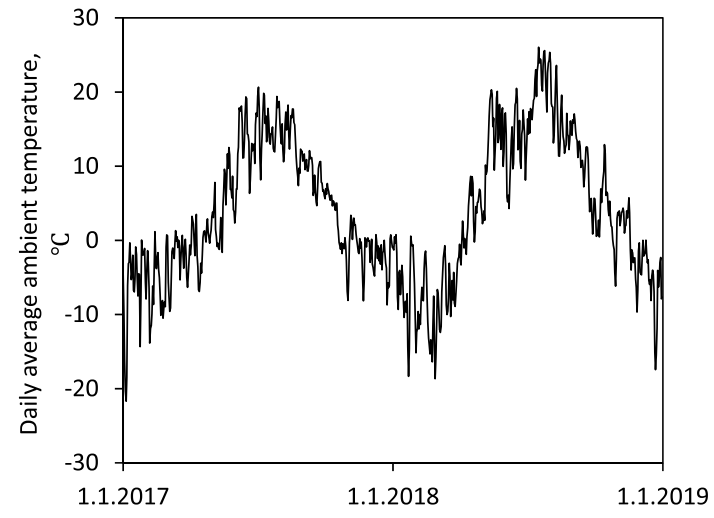

Fig. 3 The daily average temperature during the PLS (pregnant leach solution) and water circuit balance observation period

scope of this article. However, it can be said that chemicals such as sodium hydroxide and milk of lime demanded fresh water and that the bleeding of precipitated hydroxide slurries removed solution from the PLS circuit into the water circuit through the metals recovery plant.

Moisture bound to new ore: The new ore as mined is nearly dry, with 0.5 to $1 \%$ by weight moisture. As the material is stacked in heaps and irrigated, the increase of moisture bound to the ore is $\approx 10 \%$ by weight. This value is based on earlier experience with excavations of old ore and is an average, contributing to potential error in the analysis of the PLS balance. Nevertheless, a significant amount of moisture is bound to the new ore.

Discharge of water from the mine site: To maintain a safe amount of water reserve at the mine, a certain amount must be discharged annually. This amount was carefully controlled to remain within the boundaries of the environmental permit at the mine.

\section{Results}

\section{Base Case}

The water balance in the plant is presented in two parts: the PLS circuit balance and the water circuit balance (Tables 2, 3). Positive numbers reflect an increase in volume and negative numbers a reduction in volume. The rainfall in 2017 and 2018 was 743 and $600 \mathrm{~mm}$ while ground evaporation was 260 and $314 \mathrm{~mm}$, respectively. The utilization of raw lake water by the metal plant was close to $1,000,000 \mathrm{~m}^{3}$ for both years and can be seen in Tables 2 and 3 as "added solution from metals recovery plant". In Table 2, the extra evaporation is added to explain the volume change in the pond solution over the year, which can be attributed to the high temperature generated on the heaps during the leaching process (Arpalahti and 
Table 2 PLS circuit solution balance during the observation period

\begin{tabular}{lrr}
\hline Year & \multicolumn{1}{l}{2017} & \multicolumn{1}{l}{2018} \\
\hline Pond solution volume change, $\mathrm{m}^{3}$ & $-15,000$ & $-110,000$ \\
Rainfall, $\mathrm{m}^{3}$ & $4,310,000$ & $3,480,000$ \\
From the water circuit to the PLS circuit, & $1,830,000$ & $3,370,000$ \\
$\mathrm{~m}^{3}$ & & \\
Added solution from metals recovery & 400,000 & $1,020,000$ \\
$\quad$ plant, $\mathrm{m}^{3}$ & & \\
Ground evaporation, $\mathrm{m}^{3}$ & $-1,510,000-1,820,000$ \\
Ore moisture increase, $\mathrm{m}^{3}$ & $-1,750,000-1,790,000$ \\
Extra evaporation, $\mathrm{m}^{3}$ & $-3,300,000-4,370,000$ \\
\hline
\end{tabular}

Table 3 Water circuit solution balance during the observation period

\begin{tabular}{lrr}
\hline Year & \multicolumn{2}{c}{2017} \\
\hline Pond water volume change, $\mathrm{m}^{3}$ & $-1,330,000$ & $-750,000$ \\
Rainfall, $\mathrm{m}^{3}$ & $7,990,000$ & $7,980,000$ \\
Ground evaporation, $\mathrm{m}^{3}$ & $-2,810,000$ & $-4,180,000$ \\
Added solution from metals recovery & 530,000 & $-590,000$ \\
$\quad$ plant, $\mathrm{m}^{3}$ & & \\
From the water circuit to the PLS circuit, $^{3}$ & $-1,830,000$ & $-3,370,000$ \\
$\mathrm{~m}^{3}$ & & \\
Discharge of waters from the site, $\mathrm{m}^{3}$ & $-5,240,000$ & $-2,510,000$ \\
Balance uncertainties, $\mathrm{m}^{3}$ & 30,000 & $1,920,000$ \\
\hline
\end{tabular}

Lundström 2017). In Table 3, the balance uncertainties are the difference between the calculated balance pond volume change and the actual volume change. A higher error was monitored for 2018. It can be seen from Table 2 that the ground evaporation and extra evaporation together are larger than the rainfall for both of the observed years. This, in addition to the moisture needed by the new ore, accounted for $1,830,000 \mathrm{~m}^{3}$ and $3,370,000 \mathrm{~m}^{3}$ of solution being transferred from the water circuit to the PLS circuit in 2017 and 2018, respectively. Incidentally, it can be seen from Table 3 that the $3,370,000 \mathrm{~m}^{3}$ transferred from the water circuit to the PLS circuit in 2018 was more than the discharged 2,510,000 $\mathrm{m}^{3}$. Even though the PLS circuit balance at the site needs additional water, the catchment area of the water circuit is large enough that there would be a need for the discharge of waters from the site to adjacent water bodies in years similar in rainfall and evaporation to 2017 and 2018.

The base case with max. rain and min. evaporation, i.e. an increase in annual net precipitation from 600 to $1000 \mathrm{~mm}$ and a decrease in ground evaporation from 314 to $230 \mathrm{~mm}$, suggested an increase of up to $5,800,000 \mathrm{~m}^{3}$ in rainfall as well as a decrease in ground evaporation down to $-1,334,000 \mathrm{~m}^{3}$. This is a $169 \%$ higher net precipitation (rainfall minus ground evaporation), i.e. $4,466,000 \mathrm{~m}^{3}$, than the base case (2018) of 1,660,000 $\mathrm{m}^{3}$. Similarly, the base case with min. rain and max. evaporation was calculated, i.e. a decrease in annual precipitation down to $500 \mathrm{~mm}$ and an increase in ground evaporation from 314 to $355 \mathrm{~mm}$. This sub-scenario suggested $2,900,000 \mathrm{~m}^{3}$ rainfall and $-2,059,000 \mathrm{~m}^{3}$ ground evaporation. These balances are shown in Tables 4 and 5. The greatest effect of the maximum net precipitation of water can be seen in the discharge of waters from the site, which increased from $2,510,000 \mathrm{~m}^{3}$ to $8,977,000 \mathrm{~m}^{3}$, or by $258 \%$. Correspondingly, in the minimum net precipitation case, the discharge of waters resulted in a positive value in the balance, signifying that no discharge is needed (from the perspective of the PLS and water balances alone) and more lake water is needed during dry years - an increase from $1,000,000 \mathrm{~m}^{3}$ to $3,960,500 \mathrm{~m}^{3}$, or by $296 \%$.

\section{Antofagasta Case and Non-heat Generation Case}

The dry climate in the Antofagasta case showed that the increase in the required fresh water was $\approx 746 \%$ higher in an arid climate compared to the Terrafame base case. It was modeled that $8,460,000 \mathrm{~m}^{3}$ of fresh water would be required in the Antofagasta case, whereas the base case required only an addition of $1,000,000 \mathrm{~m}^{3}$ of fresh water. The amount of fresh water required in the Antofagasta case corresponds to $850 \mathrm{~m}^{3} / \mathrm{h}$ every hour, around the year. On the other hand, considering a non-heat generating heap leach process hypothetically located in Finland (non-heat generation case), the
Table 4 PLS circuit solution balance for the maximum and minimum annual net precipitation

\begin{tabular}{lcc}
\hline Scenario & $\begin{array}{l}\text { Base case with max. rain } \\
\text { and min. evaporation }\end{array}$ & $\begin{array}{l}\text { Base case with min. rain } \\
\text { and max. evaporation }\end{array}$ \\
\hline Pond solution volume change, $\mathrm{m}^{3}$ & 0 & 0 \\
Rainfall, $\mathrm{m}^{3}$ & $5,800,000$ & $2,900,000$ \\
From the water circuit to the PLS circuit, $\mathrm{m}^{3}$ & 674,000 & $4,299,000$ \\
Added solution from metals recovery plant, $\mathrm{m}^{3}$ & $1,020,000$ & $1,020,000$ \\
Ground evaporation, $\mathrm{m}^{3}$ & $-1,334,000$ & $-2,059,000$ \\
Ore moisture increase, $\mathrm{m}^{3}$ & $-1,790,000$ & $-1,790,000$ \\
Extra evaporation, $\mathrm{m}^{3}$ & $-4,370,000$ & $-4,370,000$ \\
\hline
\end{tabular}


discharge of waters would increase from $2,510,000 \mathrm{~m}^{3}$ to $6,853,000 \mathrm{~m}^{3}$ compared to 2018 , i.e. an increase of $173 \%$. This difference would be fairly similar to the extreme net precipitation case, and naturally, these scenarios are cumulative. In addition, the modeled metal recovery plant balance had to be adjusted to remove solution from the PLS circuit in this scenario. This could be achieved by treating the recovered metal solution with lime, but this would result in additional costs and tailings (Tables 6 and 7).

\section{The RCP4.5 and RCP8.5 Climate Change Scenarios}

The climate change scenarios showed that the change would be more profound during dry and hot years rather than wet and cold years. During the maximal rain/minimum evaporation scenarios, the required discharge from the site increased only 5\% in both the RCP4.5 and RCP8.5 cases, compared with the base case with similar conditions (Tables 8,9). Yet during the minimum rain, maximum evaporation scenarios, the required raw water amount increased by $46 \%$ and $83 \%$ in the RCP4.5 and RCP8.5 cases, respectively, compared with the base case with similar conditions (Tables 10,11). This is in accordance with the estimated numbers; ground evaporation would increase
Table 5 Water circuit solution balance for the maximum and minimum annual net precipitation
Table 6 PLS circuit solution balance for the Antofagasta case and the non-heat generation case

\begin{tabular}{lll}
\hline Scenario & $\begin{array}{l}\text { Base case with max. rain } \\
\text { and min. evaporation }\end{array}$ & $\begin{array}{l}\text { Base case with min. } \\
\text { rain and max. evapora- } \\
\text { tion }\end{array}$ \\
\hline Pond solution volume change, $\mathrm{m}^{3}$ & 0 & 0 \\
Rainfall, $\mathrm{m}^{3}$ & $13,300,000$ & $6,650,000$ \\
Ground evaporation, $\mathrm{m}^{3}$ & $-3,059,000$ & $-4,721,500$ \\
Added solution from metals recovery plant, $\mathrm{m}^{3}$ & $-590,000$ & $-590,000$ \\
From the water circuit to the PLS circuit, $\mathrm{m}^{3}$ & $-674,000$ & $-4,299,000$ \\
Discharge of waters from the site, $\mathrm{m}^{3}$ & $-8,977,000$ & $2,960,500$ \\
Balance uncertainties, $\mathrm{m}^{3}$ & 0 & 0 \\
\hline
\end{tabular}

\begin{tabular}{lll}
\hline & Antofagasta case & $\begin{array}{l}\text { Non-heat } \\
\text { generation } \\
\text { case }\end{array}$ \\
\hline Pond solution volume change, $\mathrm{m}^{3}$ & 0 & 0 \\
Rainfall, $\mathrm{m}^{3}$ & 10,000 & $4,234,000$ \\
From the water circuit to the PLS circuit, $\mathrm{m}^{3}$ & $6,870,000$ & 0 \\
Added solution from metals recovery plant, $\mathrm{m}^{3}$ & $1,020,000$ & $-704,000$ \\
Ground evaporation, $\mathrm{m}^{3}$ & $-1,740,000$ & $-1,740,000$ \\
Ore moisture increase, $\mathrm{m}^{3}$ & $-1,790,000$ & $-1,790,000$ \\
Extra evaporation, $\mathrm{m}^{3}$ & $-4,370,000$ & 0 \\
\hline
\end{tabular}

\begin{tabular}{lll}
\hline & Antofagasta case & $\begin{array}{l}\text { Non-heat } \\
\text { generation } \\
\text { case }\end{array}$ \\
\hline Pond solution volume change, $\mathrm{m}^{3}$ & 0 & 0 \\
${\text { Rainfall, } \mathrm{m}^{3}}^{\text {Ground evaporation, } \mathrm{m}^{3}}$ & 23,000 & $9,709,000$ \\
${\text { Added solution from metals recovery plant, } \mathrm{m}^{3}}_{\text {From the water circuit to the PLS circuit, } \mathrm{m}^{3}}$ & $-23,000$ & $-3,990,000$ \\
Discharge of waters from the site, $\mathrm{m}^{3}$ & $-590,000$ & $1,134,000$ \\
Balance uncertainties, $\mathrm{m}^{3}$ & $-6,870,000$ & 0 \\
\hline
\end{tabular}


Table 8 PLS circuit solution balance for the RCP4.5 and $R C P 8.5$ climate change cases with max. rain and min. evaporation
Table 9 Water circuit solution balance for the RCP4.5 and $R C P 8.5$ climate change cases with max. rain and min. evaporation
Table 10 PLS circuit solution balance for the $R C P 4.5$ and $R C P 8.5$ climate change cases with min. rain and max. evaporation
Table 11 Water circuit solution balance for the RCP4.5 and $R C P 8.5$ climate change cases with min. rain and max. evaporation

\begin{tabular}{lll}
\hline & $\begin{array}{l}\text { RCP4.5 case: max. rain, } \\
\text { min. evaporation }\end{array}$ & $\begin{array}{l}\text { RCP8.5 case: max. } \\
\text { rain, min. evapora- } \\
\text { tion }\end{array}$ \\
\hline Pond solution volume change, $\mathrm{m}^{3}$ & 0 & 0 \\
Rainfall, $\mathrm{m}^{3}$ & $6,525,000$ & $6,960,000$ \\
From the water circuit to the PLS circuit, $\mathrm{m}^{3}$ & 543,861 & 536,166 \\
Added solution from metals recovery plant, $\mathrm{m}^{3}$ & $1,020,000$ & $1,020,000$ \\
Ground evaporation, $\mathrm{m}^{3}$ & $-1,928,861$ & $-2,356,166$ \\
Ore moisture increase, $\mathrm{m}^{3}$ & $-1,790,000$ & $-1,790,000$ \\
Extra evaporation, $\mathrm{m}^{3}$ & $-4,370,000$ & $-4,370,000$ \\
\hline
\end{tabular}

\begin{tabular}{lll}
\hline & $\begin{array}{l}\text { RCP4.5 case: max. rain, } \\
\text { min. evaporation }\end{array}$ & $\begin{array}{l}\text { RCP8.5 case: } \text { max. } \\
\text { rain, min. } \text { evapora- } \\
\text { tion }\end{array}$ \\
\hline Pond solution volume change, $\mathrm{m}^{3}$ & 0 & 0 \\
Rainfall, $\mathrm{m}^{3}$ & $14,962,500$ & $15,960,000$ \\
Ground evaporation, $\mathrm{m}^{3}$ & $-4,423,077$ & $-5,402,932$ \\
Added solution from metals recovery plant, $\mathrm{m}^{3}$ & $-590,000$ & $-590,000$ \\
From the water circuit to the PLS circuit, $\mathrm{m}^{3}$ & $-543,861$ & $-536,166$ \\
Discharge of waters from the site, $\mathrm{m}^{3}$ & $-9,405,562$ & $-9,430,902$ \\
Balance uncertainties, $\mathrm{m}^{3}$ & 0 & 0 \\
\hline
\end{tabular}

\begin{tabular}{lll}
\hline & $\begin{array}{l}\text { RCP4.5 case: min. rain, } \\
\text { max. evaporation }\end{array}$ & $\begin{array}{l}\text { RCP8.5 case: min. } \\
\text { rain, max. evapora- } \\
\text { tion }\end{array}$ \\
\hline Pond solution volume change, $\mathrm{m}^{3}$ & 0 & 0 \\
Rainfall, $\mathrm{m}^{3}$ & $3,262,500$ & $3,480,000$ \\
From the water circuit to the PLS circuit, $\mathrm{m}^{3}$ & $4,854,655$ & $5,296,691$ \\
Added solution from metals recovery plant, $\mathrm{m}^{3}$ & $1,020,000$ & $1,020,000$ \\
Ground evaporation, $\mathrm{m}^{3}$ & $-2,977,155$ & $-3,636,691$ \\
Ore moisture increase, $\mathrm{m}^{3}$ & $-1,790,000$ & $-1,790,000$ \\
Extra evaporation, $\mathrm{m}^{3}$ & $-4,370,000$ & $-4,370,000$ \\
\hline
\end{tabular}

\begin{tabular}{lll}
\hline & $\begin{array}{l}\text { RCP4.5 case: min. rain, } \\
\text { max. evaporation }\end{array}$ & $\begin{array}{l}\text { RCP8.5 case: min. } \\
\text { rain, max. evapora- } \\
\text { tion }\end{array}$ \\
\hline Pond solution volume change, $\mathrm{m}^{3}$ & 0 & 0 \\
Rainfall, $\mathrm{m}^{3}$ & $7,481,250$ & $7,980,000$ \\
Ground evaporation, $\mathrm{m}^{3}$ & $-6,826,924$ & $-8,339,308$ \\
Added solution from metals recovery plant, $\mathrm{m}^{3}$ & $-590,000$ & $-590,000$ \\
From the water circuit to the PLS circuit, $\mathrm{m}^{3}$ & $-4,854,655$ & $-5,296,691$ \\
Discharge of waters from the site, $\mathrm{m}^{3}$ & $4,790,329$ & $6,245,999$ \\
Balance uncertainties, $\mathrm{m}^{3}$ & 0 & 0 \\
\hline
\end{tabular}


more than precipitation in dry years and even make net negative precipitation possible in the RCP8.5 case.

\section{Discussion}

The greatest differences between the water balance scenarios were found in the discharge of waters from the mine site and freshwater use. The calculated values are summarized in Table 12. Table 12 also clearly shows the importance of heat generation at the heap, specifically in Nordic climate conditions: if such a phenomenon did not take place, there would be a strong need to bleed the PLS (by neutralization with milk of lime - the effect can be seen in the effect of the metals plant on the PLS balance, changing from $1,020,000 \mathrm{~m}^{3} / \mathrm{a}$ to $-704,000 \mathrm{~m}^{3} / \mathrm{a}$ ) and significantly more water would be discharged, as they could not be fed to make up the water lost at the heaps. The scenarios also predict that there could be years, even during the current operation of Terrafame in Finland, when there would be no need to discharge water from the mine site and even the requirement of fresh water in excess of the metal recovery plant requirements.

Table 8 also shows that while there would be no such issue with discharging waters if the orebody was located in the Antofagasta Mountains, the need for fresh water would be quite high. The average hydrometallurgical water usage in 2006 in Chile was $0.13 \mathrm{~m}^{3} /$ ton of mineral (not specified tonnes or tons; Brantes and Olivares 2008). The value in Table 8 of $8,460,000 \mathrm{~m}^{3} /$ a corresponds to $18,000,000$ metric tons of ore/a, and the unit consumption is $0.47 \mathrm{~m}^{3} /$ metric ton of ore-over three times the average usage and more than the range of usage mentioned, up to $0.25 \mathrm{~m}^{3} /$ ton of mineral (Brantes and Olivares 2008). On the other hand, concentrator operations used $0.79 \mathrm{~m}^{3} /$ ton of mineral water in 2006 (Brantes and Olivares 2008), which is to say that the consumption of water in this scenario would not be exceptional. Nevertheless, this could mean that some measures would need to be considered to limit the amount of evaporative losses if such a high heat-generating orebody were located in such an arid climate. However, if the evaporation losses were limited by, for example, covering the heap, then the heat loss associated with evaporation would be limited, which then again would require an extra system to cool the heaps. It could be that such a cooling system does not exist today among currently available technologies, especially considering that the mines tend to be located at a significant distance from sources requiring district heat.

The effects of climate change appear to negate the increased precipitation with increased ground evaporation in the wet scenarios (maximum rain, minimum evaporation), as the difference is relatively small compared to the base case. However, in the dry scenarios (minimum rain, maximum evaporation), the increment of ground evaporation is much more than the increase in precipitation, leading to a much higher demand for freshwater.

\section{Conclusions}

With the increasing need in the near future for battery metals, and to achieve the global goal of responsible production, it is essential to understand the water balance in mining, and its dependency not only from the process chemistry point of view, but also with different climate scenarios. Somewhat surprisingly, the challenge of climate change would appear to lie in the need for raw water rather than in a vastly increased water discharge requirement. The current research presents the necessity of heat generation in heap leaching to keep the heap leach operation water balance feasible in a boreal black-schist ore plant such as Terrafame. The annual precipitation and evaporation play a large role in the required amount of discharge. If the operation were located in a dry area, such as the Antofagasta region in Chile, the water consumption would be over three times the typical
Table 12 Comparison of freshwater usage and discharge of waters between the scenarios

\begin{tabular}{lllc}
\hline Scenario & $\begin{array}{l}\text { Fresh water } \\
\text { usage, } \mathrm{m}^{3} / \mathrm{a}\end{array}$ & $\begin{array}{l}\text { Discharge of } \\
\text { water, } \mathrm{m}^{3} / \mathrm{a}\end{array}$ & $\begin{array}{r}\text { Effect of metals plant on } \\
\text { the PLS balance, } \mathrm{m}^{3} / \mathrm{a}\end{array}$ \\
\hline Base case 2017 & $1,000,000$ & $5,240,000$ & 400,000 \\
Base case 2018 & $1,000,000$ & $2,510,000$ & $1,020,000$ \\
Base case max. rain, min. evaporation & $1,000,000$ & $8,977,000$ & $1,020,000$ \\
Base case min. rain, max. evaporation & $3,960,500$ & 0 & $1,020,000$ \\
Antofagasta case & $8,460,000$ & 0 & $1,020,000$ \\
Non-heat generation case & $1,000,000$ & $6,853,000$ & $-704,000$ \\
RCP4.5 case: max. rain, min. evaporation & $1,000,000$ & $9,405,562$ & $1,020,000$ \\
RCP8.5 case: max. rain, min. evaporation & $1,000,000$ & $9,430,902$ & $1,020,000$ \\
RCP4.5 case: min. rain, max. evaporation & $5,790,329$ & 0 & $1,020,000$ \\
RCP8.5 case: min. rain, max. evaporation & $7,245,999$ & 0 & $1,020,000$ \\
\hline
\end{tabular}


hydrometallurgical operation use of water in the region, due to the heavy evaporation generated by the reacting sulfides. In general, the results present scenarios that highlight the role not only of technological or metallurgical process design, but also the geographical location and its climate characteristics.

Acknowledgements Open access funding provided by Aalto University. This paper is supported by Terrafame, which provided all the raw material, process data, and analysis for the research. In addition, the BATCircle project (Grant 4853/31/2018) is gratefully acknowledged (ML).

Open Access This article is licensed under a Creative Commons Attribution 4.0 International License, which permits use, sharing, adaptation, distribution and reproduction in any medium or format, as long as you give appropriate credit to the original author(s) and the source, provide a link to the Creative Commons licence, and indicate if changes were made. The images or other third party material in this article are included in the article's Creative Commons licence, unless indicated otherwise in a credit line to the material. If material is not included in the article's Creative Commons licence and your intended use is not permitted by statutory regulation or exceeds the permitted use, you will need to obtain permission directly from the copyright holder. To view a copy of this licence, visit http://creativecommons.org/licenses/by/4.0/.

\section{References}

Arpalahti A, Lundström M (2017) Heat generation in a production scale sulphide heap leach operation. Proc, European Metallurgical Conf, Production and Recycling of Non-ferrous Metals: Saving Resources for a Sustainable Future 2:727-737

AVI (Aluehallintovirasto, Regional State Administrative Agencies of Finland) (2008) Boliden Kokkola Oy:n Kokkolan sinkkitehtaan ympäristölupahakemus, 14.5.2008, (Environmental permit application of Boliden Kokkola Ltd. Zinc plant). www.ymparisto.fi/ download/noname/\%7BD40AD4E3.../83709. Accessed 2019_ 05-12 [in Finnish]

AVI (Aluehallintovirasto, Regional State Administrative Agencies of Finland) (2013) Lupa Kittilän kaivoksen toiminnan laajentamiseen, 26.6.2014, (Permit for extending the mine operation at Kittilä mine) https://www.avi.fi/documents/10191/56958/psavi_paato s_72_2013_1-2013-06-26.pdf/68dd28c2-8036-4107-9b17-01c0c 5c87b76, accessed 2019-05-12 [in Finnish]

AVI (Aluehallintovirasto, Regional State Administrative Agencies of Finland) (2014a) Kevitsan kaivoksen tuotannon laajentamisen ympäristö- ja vesitalouslupa sekä töiden ja toiminnanaloittamislupa, 11.7.2014 (Environmental and water permit for increasing the Kevitsa mine production and permit for commencing the works and operations). https://tietopalvelu.ahtp.fi/Lupa/Lisat iedot.aspx?Asia_ID=891240, accessed 2019-05-12 [In Finnish]

AVI (Aluehallintovirasto, Regional State Administrative Agencies of Finland) (2014b) Norilsk Nickel Harjavalta Oy:n kemikaalitehtaan, nikkelituotannon ja vaarallisten jätteiden kaatopaikan ympäristölupien lupamääräysten tarkastamista koskeva hakemus sekä hakemus päätöksen noudattamiseksi muutoksenhausta huolimatta koskien kobolttisulfaattituotannon aloittamista, 10.12.2014 (Application of dangerous waste environmental permit review and application of starting of production of cobalt sulfate despite the ongoing appealing process at Norilsk Nickel Harjavalta Ltd), accessed 2019-05-12, https://tietopalvelu.ahtp.fi/Lupa/AvaaL iite.aspx?Liite_ID=1441593 [in Finnish]

AVI (Aluehallintovirasto, Regional State Administrative Agencies of Finland) (2015) Metsä Fibre Oy:n biotuotetehtaan, kuoren kuivauksen ja kaasutuslaitoksen, mädättämön, integraatissa syntyvien jätevesien ja Äänekosken kaupungin yhdyskuntavesien yhteiskäsittelyn sekä Metsä Board Oyj:n jätevedenpuhdistamon ympäristölupa, sekä toiminnan aloittaminen mahdollisesta muutoksen hausta huolimatta, 28.1.2015 (Environmental permit of Metsä Fibre Ltd. Bioproduct plant, bark drying and gasification plant, digester, joint processing of the waste waters of the integrate and the municipality waters of the city of Äänekoski and Metsä Board Ltd. wastewater treatment plant, and the starting of the operations despite the possible appealing process). https://tieto palvelu.ahtp.fi/Lupa/AvaaLiite.aspx?Liite_ID $=1688231$, accessed 2019-05-12 [in Finnish]

AVI (Aluehallintovirasto, Regional State Administrative Agencies of Finland) (2018) Terrafame Oy:n Sotkamon kaivoksen kaivosja metallintuotannon ympäristö- ja vesitalouslupa ja toiminnanaloittamislupa (täytetty hakudokumentaatio), 27.7.2018 (The environmental permit, water permit and commencing of operations permit of Terrafame Ltd. Sotkamo mine mining and metals production; revised application documentation). https:// tietopalvelu.ahtp.fi/Lupa/Lisatiedot.aspx?Asia_ID=1413213, accessed 2019-05-12 [in Finnish]

Attiogbe F, Nkansah A (2017) The impact of mining on the water resources in Ghana: Newmont case study at Birim North District (New Abirem). Energ Environ Res 7(2):27-36

BOM (Bureau of Meteorology, Australia) (2019) Monthly climate statistics (1939-2019) at Kalgoorlie-Boulder airport, https:// www.bom.gov.au/climate/averages/tables/cw_012038.shtml. Accessed 2019-05-12

Brantes RA, Olivares G (2008) Best practices and efficient use of water in the mining industry, Chilean Copper Commission, ISBN 978-956-8242-10-7

Chishugi JB, Alemaw BF (2009) The hydrology of the Congo river basin: a GIS-based hydrological water balance model. World Environ Water Resour Congress. https://doi.org/10.1061/41036 (342) 593

European Commission (2018) Report on raw materials for battery applications. Commission staff working document. SWD 245/2 final. Brussels, 22.11.2018

FEI (Finnish Environment Institute) (2019) Vesistöennusteet: Oulujoen vesistöalue - Jormasjärvi (Hydrological forecasts: Oulujoki drainage basin - Jormasjärvi). https://wwwi2.ymparisto. fi/i2/59/1598821001y/wqfi.html. Accessed 2019-04-30 [in Finnish]

Gasparon M, Smedley A, Jong T, Costagliola P, Benvenuti M (2007) Acid mine drainage at Mount Morgan, Queensland (Australia): experimental simulation and geochemical modelling of buffering reactions. Proc, International Mine Water Assoc (IMWA) Symp, pp 433-436

Ghorbani Y, Franzidis JP, Petersen J (2016) Heap leaching technology - current state, innovations and future directions: a review. Min Proc Ext Met Rev 37(2):73-119

ICA (International Copper Assoc) (2017) The impacts of copper mining in Chile. Economic and social implications for the country. https://sustainablecopper.org/wp-content/uploads/2018/05/ICASummary-Document-The-Impacts-of-Copper-Mining-in-Chile -FV-04.04.2018.pdf Accessed 2019-06-16

INE (Instituto Nacionales de Estadisticas, Chile) (2017) Medio ambiente, informe annual (Annual Environment Report), ISBN: 978956-323-194-6 [in Spanish]

Jhariya D, Khan R, Thakur GS (2016) Impact of mining activity on water resource: an overview study. Proc, National Seminar on 
Recent Practices \& Innovations in Mining Industry, Raipur, India, pp 271-277

Kauppila P, Räisänen ML, Myllyoja S (2011) Best environmental practices in metal ore mining. Reports of Finnish Environment Institute 29

Krogerus K, Pasanen A (2016) Management of water balance in mining areas - WaterSmart. Reports of Finnish Environment Institute 39:2016

Lo MJ (1996) The bioleaching of copper sulfide ores in saline media: shake flask studies. MS thesis, Univ of British Columbia

Munzimi YA, Hansen MC (2015) Characterizing Congo basin rainfall and climate using tropical rainfall measuring mission (TRMM) satellite data and limited rain gauge ground observations. J Appl Meteorol Clim 54:541-555

Ochieng G, Seanego ES, Nkwonta O (2010) Impacts of mining on water resources in South Africa: a review. Sci Res Essays 5(22):3351-3357

Parviainen A, Loukola-Ruskeeniemi K (2019) Environmental impact of mineralised black shales. Earth-Sci Rev 192:60-90

Punkkinen H, Räsänen L, Mroueh U-M, Korkealaakso J, Luoma S, Kaipainen T, Backnäs S, Turunen K, Hentinen K, Pasanen A, Kauppi S, Vehviläinen B, Krogerus K (2016) Guidelines for mine water management, VTT Technology 266, ISBN 978-951-38-8443-7
Ruosteenoja K (2013) Maailmanlaajuisiin ilmastomalleihin perustuvia lämpötila- ja sademääräskenaarioita (Scenarios of temperature and rainfall based on world-wide climate models), Sektoritutkimusohjelman ilmastoskenaariot (SETUKLIM) 1.osahanke, Ilmatieteen laitos (Climate scenarios of the sector research program SETUKLIM, 1. part, Finnish Meteorological Institute). https:// ilmatieteenlaitos.fi/c/document_library/get_file?uuid=c4c5b f12-655e-467a-9ee0-f06d8145aaa6\&groupId=30106 Accessed 2019-10-28 [In Finnish]

Rybnikova L, Rybnikov P (2017) Water quality of the abandoned sulfide mines of the middle Urals (Russia). Proc, IMWA Conf, pp 753-760

Sudmeyer R (2016) Climate in the Pilbara, Bull 4873, Dept of Agriculture and Food, Government of Western Australia, ISSN $1833-7236$

Swanson S, Breckenridge L, Leduc M (2016) Mine water balances - a new proposed approach. Proc IMWA Conf, pp 528-534

Terrafame (2017) Terrafame Oy:n Vesienhallinta-hankkeen YVAselostus (Environmental impact assessment of the water management of Terrafame Ltd.), https://www.ymparisto.fi/terrafamev esienhallintaYVA Accessed 2019-05-12 [in Finnish] 